\title{
Breast cancer and genetics
}

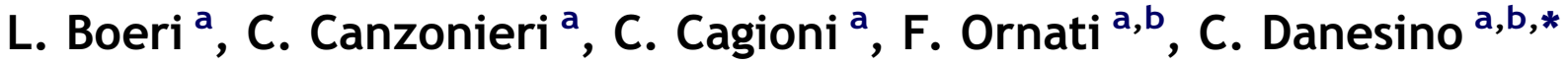

\author{
${ }^{a}$ Department of Pediatric Sciences and Human and Hereditary Pathology, University of Pavia, Italy \\ b IRCCS Foundation, Policlinico S.Matteo, Pavia, Italy
}

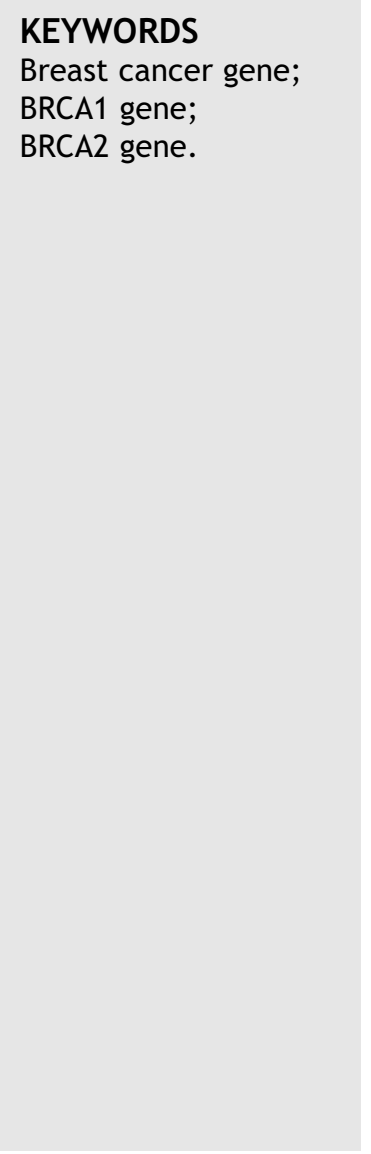

\begin{abstract}
Familiar aggregation of breast cancer has been known since Roman times, but it has been discussed in practical terms only from the 19th century. Most of the studies dealing with this issue suggest that the risk is higher in relatives of patients with early onset and that the risk also increases as a function of the bilaterality of the disease or the simultaneous presence of breast cancer and ovarian cancer.

A series of epidemiological studies consistently suggest hereditary autosomal dominant transmission with reduced penetrance. Previous epidemiological research and collection of data from families has been used only from the 1990s in order to identify disease genes. The BRCA1 gene was identified as the first gene responsible for hereditary forms of breast cancer and subsequently BRCA2. In 1995 both genes were identified and cloned, and they demonstrated to have only minimal homology. The conclusions deal with genetic counseling and the evaluation of the risk of developing cancer.
\end{abstract}

Sommario L'aggregazione familiare di casi di tumore nella mammella è nota sin dai tempi dei romani, ma viene discussa in modo concreto solo nel $19^{\circ}$ secolo quando la maggior parte degli studi suggerisce che il rischio sia maggiore per i congiunti dei casi con esordio precoce e il rischio aumenta anche in funzione della bilateralità della patologia o della contemporanea presenza di tumore della mammella e tumore ovarico.

Una serie di studi epidemiologici suggerisce, in modo consistente, una modalità di trasmissione ereditaria di tipo autosomico dominante, con penetranza ridotta.

Tutto il lavoro epidemiologico e di raccolta di famiglie ha potuto essere utilizzato solo negli anni ' 90 per arrivare ad identificare i geni malattia.

Furono identificati quello che venne definito BRCA1 come primo gene responsabile delle forme ereditarie di tumore della mammella, quindi il BRCA2. Nel 1995, entrambi i geni erano identificati e clonati, e dimostravano di avere solo minima omologia.

Nelle conclusioni vengono presi in considerazione la valutazione del rischio di sviluppare il tumore e la consulenza genetica.

(c) 2011 Elsevier Srl. All rights reserved.

\footnotetext{
* Corresponding author. Dipartimento di Scienze Pediatriche e Patologia Umana ed Ereditaria Università di Pavia, Italy. E-mail address: cidilab@unipv.it (C. Danesino).
} 


\section{Introduction}

Familial aggregation of breast cancer has been known since Roman times, but it has been seriously discussed in the medical literature only from the 19th century when the French physician Paul Broca and at the same time his colleague in London, Sir James Paget, studied the particulars of the phenomenon and collected data related to a substantial number of families which illustrated the problem [1,2].

Using the methods available at the time, it is obvious that neither Broca nor Paget managed to go beyond the collection of data and description of the cases. They did not have any data on the principles of transmission of hereditary traits in humans (even though Mendel was their contemporary), and they also did not have statistical tools or mathematical models which could help them to clarify the components of multifactorial inheritance. The role of genetic factors in the genesis of breast cancer actually remained an enigma until the end of the 20th century.

Several studies of patient populations with breast cancer (series of consecutive patients, who were not selected) have shown that the closest relatives of an affected subject have a measurable increased risk of developing the disease. These risk levels vary little among the various studies and it is interesting to note that the results are similar in different populations and ethnic groups (Table 1). It is also significant that the proportion of cases attributable to genetic factors is between $5 \%$ and $10 \%$ both in low disease incidence populations and high disease incidence populations.

Most studies suggest that the risk is higher in relatives of case patients with early onset. The study published by Houlston et al. [3] shows a direct relationship between the age of onset in the index case and the relative risk in siblings and offspring. The risk also increases as a function of the bilateral nature of the disease in the index case or the simultaneous presence of breast cancer and ovarian cancer.

Overall, these data indicate not only the existence of an important contribution of genetic factors to the development of breast cancer, but they also demonstrate that a positive family history is the strongest predictor of individual risk. Conversely, the data collection cannot show

Table 1 Family groups with breast cancer risk - Relative risk of breast cancer.

\begin{tabular}{ll}
\hline Risk group & $\begin{array}{l}\text { Relative risk of } \\
\text { breast cancer }\end{array}$ \\
\hline Familial breast cancer & 2 \\
First grade relative & $2.1-5$ \\
$\begin{array}{l}\text { First grade relative } \\
\quad \text { with onset at }<45 \text { years }\end{array}$ & 6 \\
$\begin{array}{l}\text { First grade relative } \\
\quad \text { with bilateral breast cancer }\end{array}$ & 2.5 (influenced by \\
Two first grade relatives & the age of onset) \\
& 1.4 \\
Second grade relatives & 2.3 (in females) \\
First grade relative, male & 6.1 (in males) \\
\end{tabular}

how many genes are responsible for breast cancer or define the mechanisms of hereditary transmission.

A series of epidemiological studies, among which also Jacobsen et al., 1946, Bishop et al and Go et al [4-7], consistently suggest hereditary autosomal dominant transmission with reduced penetrance.

If we consider only the autosomal dominant model and assume a penetrance of $80 \%$ related to the entire life course, it can be calculated that the total number of breast cancers caused by the effect of a primary single gene is between $2.5 \%$ and $10 \%$ in the Western world. In cases with onset before 30 years of age, the estimated percentage rises to about $35 \%$ whereas it drops to about $1 \%$ in cases with onset after 80 years of age.

Both epidemiological research and the study of particularly large families has allowed us to hypothesize the presence of genetic heterogeneity and the possibility that more than one type of cancer aggregate in some families. The association of breast cancer and ovarian cancer in the same families is well defined now, but there is also reasonable evidence of an increased risk of cancer of the colon and rectum, prostate and endometrium at least in some families (Table 2).

The results of the epidemiological research and collection of family data was used only in the early 1990s in order to identify disease genes. In that year, linkage was found in a subgroup of families with breast cancer characterized by onset before the age of 45 (logarithm of the odds (LOD) score +5.98 ) with polymorphic markers on chromosome 17 in q21. A few years later, in 1993, Easton et al studied 214 families and identified BRCA1 as the first gene responsible for hereditary forms of breast cancer. There was a strong linkage in most of the families affected by breast cancer and ovarian cancer, but only in $45 \%$ of the families affected by breast cancer only. The linkage was much stronger in families where onset occurred before the age of 45 , while there was evidence against linkage in families with one or more cases of breast cancer in males. These data were important as they showed that there was genetic heterogeneity and thereby suggested that other genes might have a role in the genesis of cancer. Data related to genetic linkage analysis were also useful to calculate the frequency of BRCA1 gene mutations in the population which proved to be about 0.0007 (i.e. approximately one woman out of every 700 is a heterozygous carrier of the gene mutation).

The next step was obviously to collect data from a large number of families in which linkage analysis allowed exclusion of BRCA1 gene involvement (total LOD score -16.63) and subsequently use this result to identify other genes. The attempt was successful, and allowed the identification of the BRCA2 gene on chromosome 13 in q12-13, located proximal to the retinoblastoma gene. By the end of 1995, both genes were identified and cloned, and proved to have only minimal homology (Table 3 ).

\section{BRCA1}

The BRCA1 gene spans more than $80 \mathrm{~kb}$ of genomic DNA and encodes a $7.8 \mathrm{~kb}$ transcript composed of 24 coding exons. 
Table 2 List of some rare, inherited syndromes associated with increased risk of breast and ovarian cancer.

\begin{tabular}{|c|c|}
\hline Syndrome & Features \\
\hline \multicolumn{2}{|c|}{ Body_ID: T093002.50 } \\
\hline Cowden & $\begin{array}{l}\text { Multiple hamartoma of the skin and oral mucosa, adenoma of the thyroid, gastrointestinal tract and } \\
\text { central nervous system. Autosomal dominant. Up to } 50 \% \text { risk for a female of developing breast cancer. } \\
\text { Germline mutations in the PTEN gene (or MMAC) on chromosome } 10 \text { are responsible for the disease } \\
\text { in some families. }\end{array}$ \\
\hline \multicolumn{2}{|c|}{ Body_ID: T093002.100 } \\
\hline Gorlin & $\begin{array}{l}\text { Multiple nevoid basal cell carcinoma at a variable degree of malignancy, agenesis of the corpus callosum, } \\
\text { increased frequency of breast cancer. Autosomal dominant. Gene (PTCH1) located to } 9 q 31 \text {. }\end{array}$ \\
\hline \multicolumn{2}{|c|}{ Body_ID: T093002.150 } \\
\hline Li-Fraumeni & $\begin{array}{l}\text { Typically early onset of breast cancer in women and excess of childhood sarcomas, acute leukemia, etc. } \\
\text { The presence of multiple primary tumors is frequent. Some of the cases are caused by germline mutations } \\
\text { in p53 (chromosome 17p13); in a minority the mutation is in Chk2 (chromosome 22q12) but in other families } \\
\text { the cause is unknown. Autosomal dominant. }\end{array}$ \\
\hline Muir-Torre & $\begin{array}{l}\text { Skin lesions associated with colorectal, larynx cancer or duodenal cancer and excess of breast, ovary, } \\
\text { bladder, esophagus and uterus cancer. Gene located on chromosome } 2 \mathrm{p} \text {, (same location as hMSH2). } \\
\text { Autosomal dominant. }\end{array}$ \\
\hline Reifenstein & $\begin{array}{l}\text { Males with hypospadias and other signs of inadequate androgen effect due to resistance to androgens. } \\
\text { The condition can develop breast cancer in males. Androgen receptor gene mutation on chromosome } \mathrm{X} \text {. }\end{array}$ \\
\hline Peutz-Jegher & $\begin{array}{l}\text { Hyperpigmentation particularly of the mouth, multiple hamartomas of the small intestine but excess of } \\
\text { other types of cancer including breast cancer. STK11 mutations in the gene located on chromosome 19p } \\
\text { in some families. Autosomal dominant. }\end{array}$ \\
\hline
\end{tabular}

\section{Pathological alleles}

More than 1600 BRCA1 gene mutations have been identified [8]. While a small number of these mutations have been identified repeatedly in unrelated families, most of the mutations were observed in only one or a few families. Although some studies have suggested differences in the degree of risk associated with different mutations, definitive data on this point are not yet available. A number of people, i.e. between $10 \%$ and $15 \%$ of patients who undergo genetic testing, present variants of uncertain significance in the sense that it is still not possible to define whether the mutations are associated with an increased risk of tumor transformation or whether the variants have no pathological significance.

Examples of pathological variants may be:

c.68 69delAG(185delAG or 187delAG); p.Glu23ValfsX17 c.5266dupC(5385insC or 5382insC); p.Gln1756ProfsX74

\section{Gene product}

The BRCA1 gene encodes a $220 \mathrm{kd}$ protein composed of 1863 amino acids. The breast cancer type 1 susceptibility protein (BRCA1) is normally localized in the nucleus and contains phosphorylated residues. It also contains some recognizable regions including a RING finger domain near the $\mathrm{N}$-terminal residue, which are two nuclear localization signals located on the exon 11, an SQ cluster between aa 1280-1524 and a BRCT C-terminus domain. The BRCA1 gene interacts with many proteins involved in pathways such as cell cycle progression, transcriptional regulation, DNA damage response and ubiquitination. The BRCA1 gene is expressed in most tissues and cell types thereby suggesting that the mode of expression alone is not sufficient to induce a phenotype restricted to ovarian cancer and breast cancer. BRCA1 gene transcription is induced at the end of the G1 phase of the cell cycle and remains elevated in the $\mathrm{S}$ phase suggesting a role in the DNA synthesis; more recent data suggest a role of the DNA repair protein.

Table 3 A summary of the main characteristics of the two genes.

\begin{tabular}{|c|c|c|c|c|}
\hline Gene & Cromosome & Protein & Locus specific & HGMD \\
\hline$B R C A 1$ & $17 q 21$ & $\begin{array}{l}\text { Breast cancer type } 1 \\
\text { susceptibility protein }\end{array}$ & $\begin{array}{l}\text { Catalog of Somatic Mutations in Cancer } \\
\text { (COSMIC)-Breast-Cancer } \\
\text { http://genomed.org/LOVD/LQTs/home.php?select_db=BRCA1 }\end{array}$ & BRCA1 \\
\hline$B R C A 2$ & $13 q 12.3$ & $\begin{array}{l}\text { Breast cancer type } 2 \\
\text { susceptibility protein }\end{array}$ & $\begin{array}{l}\text { Catalog of Somatic Mutations in Cancer } \\
\text { (COSMIC)-Breast-Cancer } \\
\text { Fanconi Anemia Mutation Database (FANCD1 - BRCA2) } \\
\text { http://genomed.org/LOVD/LQTs/home.php?select_db=BRCA2 }\end{array}$ & BRCA2 \\
\hline
\end{tabular}


Knockout (KO) mice were developed and further research showed that the complete absence of the BRCA1 gene leads to embryonic lethality due to absence of cell proliferation. Cells derived from BRCA1-deficient mice show deficits in DNA repair. Available evidence indicates that the BRCA1 gene (like TP53) functions as a caretaker, which helps maintain genomic integrity.

\section{Mutated gene product}

Most BRCA1 mutations lead to frameshifts [9] resulting in the absence of protein or the presence of non-functional proteins. In all studied tumor specimens originating from subjects with germline BRCA1 gene mutations, the normal allele was deleted or inactivated thereby leading to a biallelic loss of BRCA1. This finding strongly suggests that BRCA1 is a tumor-suppressor gene whose loss causes genomic instability and susceptibility to malignant transformation.

\section{BRCA2}

The BRCA2 gene encodes a $10.4 \mathrm{~kb}$ transcript containing 27 exons.

\section{Pathological alleles}

More than 1880 pathogenic mutations have been identified. Between $10 \%$ and $15 \%$ of patients who undergo genetic testing show variants of uncertain significance in the sense that it is still not possible to define whether the mutations are associated with an increased risk of tumor transformation or whether the variants have no pathological significance.

Examples of variants with established pathological significance:

c.5946delT, p.Ser1982ArgfsX22

c.771_775delTCAAA, p.Asn257LysfsX17

\section{Gene product}

The BRCA2 gene encodes a $380 \mathrm{kd}$ protein consisting of 3418 amino acids. Eight DNA motifs $[10,11]$ of $30-40$ residues located in the exon 11 are necessary to facilitate binding of the breast cancer type 2 susceptibility protein (BRCA2) to RAD51. The BRCA2 gene is usually located in the nucleus and contains phosphorylated residues. Although the BRCA2 protein has no apparent relation to the BRCA1 protein, the two proteins share a similar set of functions which explain how their mutations may result in a hereditary predisposition to the development of breast and ovarian cancer. Also the BRCA2 gene is expressed in most tissues; its transcription is induced at the end of the G1 phase of the cell cycle and seems to be involved in the DNA repair processes by interacting with the RAD51 protein. Also complete loss of the protein function of the BRCA2 gene causes embryonic lethality in $\mathrm{KO}$ mice.

Cells derived from mouse embryos lacking the BRCA2 gene show deficits in DNA repair capacity and are more sensitive to the effect of radiation. It should be kept in mind that the findings related to the function of this gene may have immediate relevance to mammography screening and the various treatment modalities. It is possible that the BRCA2 gene is involved also in a number of cellular processes of which only some are related to the etiology of breast and ovarian cancer.

\section{Mutated gene product}

Most gene mutations reported to date are frameshifts, deletions, insertions, and nonsense mutations leading to the formation of truncated proteins; this is consistent with the loss of function which is expected in clinically meaningful mutations of tumor suppressor genes [12].

The set of data obtained from formal and molecular genetics are usable in the context of genetic counseling. Genetic counseling is the process by which patients or relatives are provided with information on the nature, inheritability and effects of genetic disorders in order to help them make informed medical decisions.

\section{Mode of inheritance}

Germline mutations of BRCA1 and BRCA2 genes are inherited as an autosomal dominant inheritance.

\section{Conclusions}

\section{Family risk assessment}

Parents of index cases who are BRCA1/2 gene mutation carriers

Virtually all patients with BRCA1 or BRCA2 germline mutations have inherited the mutation from one of the genotypes.

- The parent may or may not have developed cancer as a function of the penetrance of the mutation, sex, age and other variables.

- Both parents of a patient with BRCA1 or BRCA2s germline mutations should be offered the possibility to undergo genetic testing to define which part of the family is at risk.

- In some cases neither parent is identified as a carrier of the gene mutation; the percentage of de novo mutation events is not precisely known, but it is believed to be small.

\section{Siblings of index cases who are BRCA1/2 gene mutation carriers}

- The risk to siblings of an index case depends on the presence or absence of the gene mutation in the parents.

- The risk to siblings of an index case of inheriting BRCA1 or BRCA2 gene mutation is $50 \%$ if one parent has germline mutation in one of the two genes. 
- The risk to siblings of an index case of developing cancer is, however, strongly influenced by variables such as the penetrance of the mutation and mainly sex and age.

\section{Children of index cases who are BRCA1/2 gene mutation carriers}

- The children of a patient carrying a BRCA1 or BRCA2 germline mutation have a $50 \%$ possibility of inheriting the mutation.

- The risk of developing cancer is, however, strongly influenced by variables such as the penetrance of the mutation and mainly sex and age.

\section{Other relatives of index cases who are BRCA1/2 gene mutation carriers}

The risk to other family members will always be assessed on the basis of the position in the pedigree and information related to the distribution of the mutation in the family.

\section{Assessment of the risk of developing cancer and genetic counseling}

\section{Asymptomatic adult family members}

In general, the family of a person who is a carrier of a BRCA1 or BRCA2 germline mutation should receive accurate genetic counseling about their risk of having inherited the same mutation, the possibility to undergo genetic testing, their risk of developing cancer (it should be noted that the risk of developing cancer is to be kept distinct from the probability of having inherited the mutation) and finally about the options related to anti-tumor screening and prophylactic surgery.

\section{Absence of gene mutations \\ Relatives at risk who have not inherited the germline mutation can be defined as being at risk in line with the general population; they may also be more at risk based on the presence of personal risk factors. The guidelines for cancer prevention should be applied to these people. \\ Note: This assumption does NOT apply to people who do not have identifiable BRCA1 or BRCA2 gene mutations, if the index case of the family has not been tested or a gene mutation has not been identified.}

\section{Assessment of gene mutations in young relatives at risk} Legitimate doubts have been expressed related to the screening of subjects at risk for all genetically determined diseases before the age of 18 , and this principle applies also to the testing for BRCA1 and BRCA2 gene mutations. There are obvious problems in connection with the wording of an appropriate informed consent form for children and adolescents under 18 as well as the lack of surveillance, prevention strategies of proven effectiveness and problems of discrimination. Based on these considerations, search for gene mutations is not considered appropriate unless there is reason to believe that the child/adolescent would benefit from immediate treatment.
Prenatal diagnosis

Identification of BRCA1 or BRCA2 germline mutations of fetal cells from chorionic villus sampling (11 weeks) or amniocentesis (16th week) is technically possible [13-15]. This test requires that the gene mutation causing the disease in the family in question has previously been identified.

Requests for prenatal diagnosis related to late-onset diseases, which do not cause impairment of intellectual functions and for which treatment options are available, are not common.

The implications of testing in connection with possible termination of pregnancy (IVG) are evident and still the subject of extensive debate.

Pre-implantation genetic diagnosis provides a viable option for families with known mutations.

\section{Conflict of interest statement}

The authors have no conflict of interest to declare.

\section{Appendix \\ Supplementary data}

Supplementary data associated with this article can be found, in the online version, at doi:10.1016/j.jus.2011.10. 002 .

\section{References}

[1] Petrucelli N, Daly MB, Feldman GL. BRCA1 and BRCA2 hereditary breast and ovarian cancer. In: Pagon RA, Bird TD, Dolan CR, Stephens K, editors. GeneReviews [Internet]. Seattle (WA): University of Washington, Seattle; 1993-1998 Sep 4. updated 2011 Jan 20.

[2] Steel CM. Cancer of the breast and female reproductive tract. Ch. 93. In: Rimoin DL, Connor JM, Yeritz REP, Korf BR, editors. Emery and Rimoin's principles and practice of medical genetics. 5th ed. New York: Churchill Livingston; 2007. p. 2093-121.

[3] Houlston RS, McCarter E, Parbhoo S, Scurr JH, Slack J. Family history and risk of breast cancer. J Med Genet 1992;29:154-7.

[4] Kvåle G, Jacobsen BK. Risk factors for breast cancer. Do epidemiologic findings provide a basis for primary prevention? Tidsskr Nor Laegeforen 1990 Jan 20;110(2):232-5.

[5] Bishop DT, Skolnick MH. Genetic epidemiology of cancer in Utah genealogies: a prelude to the molecular genetics of common cancers. J Cell Physiol Suppl 1984;3:63-77.

[6] Skolnick MH, Thompson EA, Bishop DT, Cannon LA. Possible linkage of a breast cancer-susceptibility locus to the $A B O$ locus: sensitivity of LOD scores to a single new recombinant observation. Genet Epidemiol 1984;1(4):363-73.

[7] King MC, Go RC, Elston RC, Lynch HT, Petrakis NL. Allele increasing susceptibility to human breast cancer may be linked to the glutamate-pyruvate transaminase locus. Science 1980 Apr 25;208(4442):406-8.

[8] Brody LC, Biesecker BB. Breast cancer susceptibility genes. BRCA1 and BRCA2. Medicine (Baltimore) 1998 May;77(3): 208-26.

[9] Jhanwar-Uniyal M. BRCA1 in cancer, cell cycle and genomic stability. Front Biosci 2003 Sep 1;8:s1107-17. 
[10] Glover JN. Insights into the molecular basis of human hereditary breast cancer from studies of the BRCA1 BRCT domain. Fam Cancer 2006;5(1):89-93.

[11] Irminger-Finger I, Leung WC. BRCA1-dependent and independent functions of BARD1. Int J Biochem Cell Biol 2002 Jun; 34(6):582-7.

[12] Carter RF. BRCA1, BRCA2 and breast cancer: a concise clinical review. Clin Invest Med 2001 Jun;24(3):147-57.

[13] Quinn GP, Vadaparampil ST, Bower B, Friedman S, Keefe DL. Decisions and ethical issues among BRCA carriers and the use of preimplantation genetic diagnosis. Minerva Med 2009 Oct; 100(5):371-83.

[14] Clancy T. A clinical perspective on ethical arguments around prenatal diagnosis and preimplantation genetic diagnosis for later onset inherited cancer predispositions. Fam Cancer 2010 Mar;9(1):9-14.

[15] Sagi M, Weinberg N, Eilat A, Aizenman E, Werner $M$, Girsh E, et al. Preimplantation genetic diagnosis for BRCA1/2-a novel clinical experience. Prenat Diagn 2009 May;29(5):508-13. 